\title{
Knowledgeable case selection results in favorable outcomes
}

\author{
Paul H. Sugarbaker ${ }^{1}$, Kurt Van der Speeten ${ }^{2}$ \\ ${ }^{1}$ MedStar Washington Hospital Center, Washington, DC, USA; ${ }^{2}$ Department of Surgery, Hospital Oost-Limburg, Genk, Belgium \\ Correspondence to: Paul H. Sugarbaker, MD. MedStar Washington Hospital Center, Washington, DC, USA. Email: Paul.Sugarbaker@outlook.com; \\ Kurt Van der Speeten. Department of Surgery, Hospital Oost-Limburg, Genk, Belgium. Email: Kurt.Vanderspeeten@zol.be. \\ Comment on: Manzanedo I, Pereira F, Serrano A, et al. Review of management and treatment of peritoneal metastases from gastric cancer origin. J \\ Gastrointest Oncol 2021;12:S20-9.
}

Submitted Dec 16, 2020. Accepted for publication Mar 16, 2021.

doi: 10.21037/jgo-2020-09

View this article at: http://dx.doi.org/10.21037/jgo-2020-09

This concise and comprehensive review by Manzanedo and coworkers emphasizes the need for laparoscopy to assess the volume of peritoneal disease (PCI) and assess the possibility of achieving a complete cytoreduction (CC-0) (1). Their data focuses on the 3 national registries that support cytoreductive surgery including gastrectomy plus HIPEC for low volume PM in patients with primary gastric cancer. Also, the randomized trial of Yang et al. (2) and the propensity matched study of Bonnot et al. (3) support their recommendation for treatment of these patients. They recommend preoperative FLOT for 4 cycles, complete cytoreduction including gastrectomy, then HIPEC with cisplatin at $75 \mathrm{mg} / \mathrm{m}^{2}$ for 60 minutes. They express interest in further clinical research with neoadjuvant laparoscopic HIPEC, neoadjuvant intraperitoneal and systemic chemotherapy (NIPS), and pressurized intraperitoneal aerosol chemotherapy (PIPAC) within the context of clinical trials. This well written manuscript is definitely worth the reader's time for study and evaluation. These authors convince us that careful selection of patients with gastric cancer and PM plus cytoreductive surgery (including gastrectomy) and HIPEC is a standard of care until further data become available.

\section{Acknowledgments}

Funding: None.

\section{Footnote}

Provenance and Peer Review: This article was commissioned by the editorial office, Fournal of Gastrointestinal Oncology for the focused issue "Intraperitoneal Chemotherapy for Peritoneal Metastases: HIPEC, EPIC, NIPEC, PIPAC and More". The article did not undergo external peer review.

Conflicts of Interest: Both authors have completed the ICMJE uniform disclosure form (available at http:// dx.doi.org/10.21037/jgo-2020-09). The focused issue was sponsored by the Peritoneal Surface Oncology Group International (PSOGI). Drs. PHS and KVDS served as the unpaid Guest Editors of the focused issue. The authors have no other conflicts of interest to declare.

Ethical Statement: The authors are accountable for all aspects of the work in ensuring that questions related to the accuracy or integrity of any part of the work are appropriately investigated and resolved.

Open Access Statement: This is an Open Access article distributed in accordance with the Creative Commons Attribution-NonCommercial-NoDerivs 4.0 International License (CC BY-NC-ND 4.0), which permits the noncommercial replication and distribution of the article with the strict proviso that no changes or edits are made and the original work is properly cited (including links to both the formal publication through the relevant DOI and the license). See: https://creativecommons.org/licenses/by-nc-nd/4.0/.

\section{References}

1. Manzanedo I, Pereira F, Serrano A, et al. Review of management and treatment of peritoneal metastases from gastric cancer origin. J Gastrointest Oncol 2021;12:S20-9. 
2. Yang XJ, Huang CQ, Suo T, et al. Cytoreductive surgery and hyperthermic intraperitoneal chemotherapy improves survival of patients with peritoneal carcinomatosis from gastric cancer: final results of a phase III randomized clinical trial. Ann Surg Oncol 2011;18:1575-81.

Cite this article as: Sugarbaker PH, Van der Speeten K. Knowledgeable case selection results in favorable outcomes. J Gastrointest Oncol 2021;12(Suppl 1):S30-S31. doi: 10.21037/ jgo-2020-09
3. Bonnot PE, Piessen G, Kepenekian V, et al. Cytoreductive surgery with or without hyperthermic intraperitoneal chemotherapy for gastric cancer with peritoneal metastases (CYTO-CHIP study): A propensity score analysis. J Clin Oncol 2019;37:2028-40. 